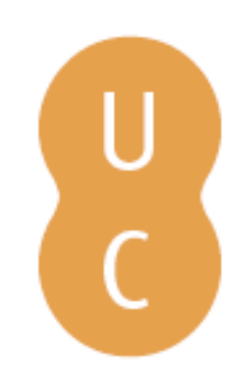

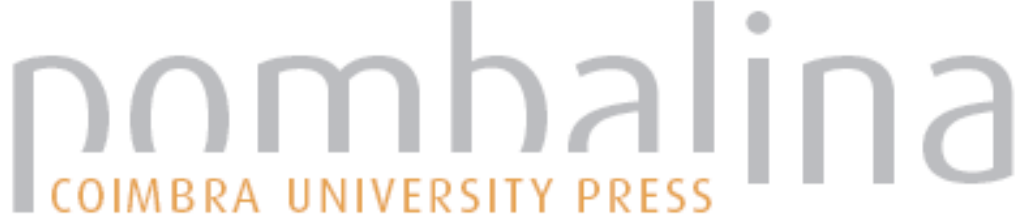

\section{A tool for mapping rural-urban interfaces on different scales}
Autor(es): $\quad$ Casula, F; Vila, B; Long Fournel, M; Pellizzaro, G; Arca, B; Tedim, F; Trebini, F; Derudas, A; Cane, S

Publicado por: Imprensa da Universidade de Coimbra

URL persistente:

URl:http://hdl.handle.net/10316.2/34214

DOI:

DOl:http://dx.doi.org/10.14195/978-989-26-0884-6_70

Accessed : $\quad$ 26-Apr-2023 14:10:03

A navegação consulta e descarregamento dos títulos inseridos nas Bibliotecas Digitais UC Digitalis, UC Pombalina e UC Impactum, pressupõem a aceitação plena e sem reservas dos Termos e Condições de Uso destas Bibliotecas Digitais, disponíveis em https://digitalis.uc.pt/pt-pt/termos.

Conforme exposto nos referidos Termos e Condições de Uso, o descarregamento de títulos de acesso restrito requer uma licença válida de autorização devendo o utilizador aceder ao(s) documento(s) a partir de um endereço de IP da instituição detentora da supramencionada licença.

Ao utilizador é apenas permitido o descarregamento para uso pessoal, pelo que o emprego do(s) título(s) descarregado(s) para outro fim, designadamente comercial, carece de autorização do respetivo autor ou editor da obra.

Na medida em que todas as obras da UC Digitalis se encontram protegidas pelo Código do Direito de Autor e Direitos Conexos e demais legislação aplicável, toda a cópia, parcial ou total, deste documento, nos casos em que é legalmente admitida, deverá conter ou fazer-se acompanhar por este aviso.

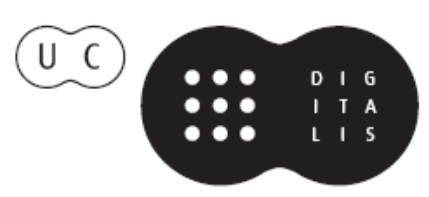




\section{ADVANCES IN}

Forest Fire

\section{RESEARCH}

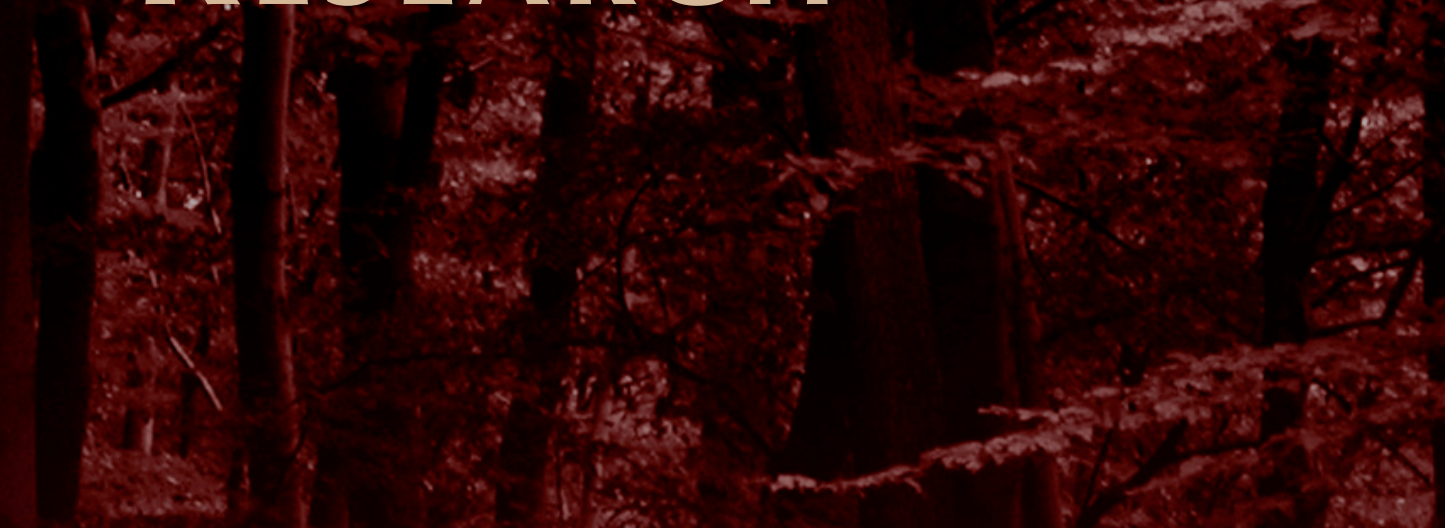

\section{DOMINGOS XAVIER VIEGAS}

\section{EDITOR}




\title{
A tool for mapping rural-urban interfaces on different scales
}

Christophe Bouillon ${ }^{\mathrm{a}}$, Fernandez Ramiro $\mathrm{MM}^{\mathrm{b}}$, Sirca $\mathrm{C}^{\mathrm{cd}}$, Fierro Garcia B ${ }^{\mathrm{b}}$, Casula $\mathrm{F}^{\mathrm{c}}$, Vila B ${ }^{\mathrm{b}}$, Long Fournel $\mathrm{M}^{\mathrm{a}}$, Pellizzaro $\mathrm{G}^{\mathrm{e}}$, Arca $\mathrm{B}^{\mathrm{e}}$, Tedim $\mathrm{F}^{\mathrm{f}}$, Trebini $\mathrm{F}^{\mathrm{c}}$, Derudas $\mathrm{A}^{\mathrm{c}}$, Cane $\mathrm{S}^{\mathrm{c}}$

${ }^{a}$ Irstea, Ecosystemes méditerranéens et risques, Aix-en-Provence, France, christophe.bouillon@irstea.fr

${ }^{b}$ Tragsatec, Madrid, Spain,mfra@tragsa.es

${ }^{c}$ Dipartimento di Scienze della Natura e del Territorio, University of Sassari, Italy,cosirca@ uniss.it

${ }^{d}$ CMCC, Euro-Mediterranean centre for Climate Change, IAFENT Division, Sassari, Italy

${ }^{e}$ Institute of Biometeorology (CNR-IBIMET), Sassari, Italy, g.pellizzaro@ibimet.cnr.it

${ }^{f}$ Faculdade de Letras, Universidade do Porto, Portugal, ftedim@letras.up.pt

\begin{abstract}
The aim of this paper is to present the methodologies, a software and results developed in the European FUME program to map the rural-urban interfaces (RUI).

Three methodologies were set up for RUI mapping: two on the local scale (the community scale) and one on the global scale (the European scale).

The first local scale method was developed in a French context by IRSTEA. In this case the RUI is defined by a radius of 100 metres around each house located at a distance inferior to 200 metres from forests or scrublands. The building density was used to create four classes of housing configuration. Then the structure of vegetation was characterized and mapped to emphasize its horizontal continuity with landscape ecology metrics. The RUI map was created by a combination of housing configuration and vegetation characterisation.

The second local scale method developed by TRAGSATEC is based on three phases. First a settlement map creation with the union of a land use cover and a vegetation cover defines the housing and the landscape that surrounds them. Then a buffer is created around settlements which are located at a distance inferior to $400 \mathrm{~m}$ from the forest; its size depends on the difficulty in protecting the houses against fire. In the final phase the different types of RUI are defined from the type of settlement and vegetation-settlement connection around houses.

The global scale method developed by IRSTEA makes possible the comparison of the situations and the importance of RUI in the different European countries.

On the global scale, the rural urban interfaces are defined by a radius of 400 metres around houses located at less than 200 metres from forests or shrubland. The global rural urban interface map results from the combination of criteria from the Corine Land Cover database and from the soil sealing database.

A major step of the work was the development of a software named RUImap with the three different methods above.

The use of the tool could be very advantageous for fire risk analysis on RUI scale, and for local quantification of fuel charge and continuity. This information linked with the direct knowledge of the general context is very important for the local fire risk assessment.
\end{abstract}

Keywords: forest fire, wildland urban interface, rural urban interface, software, geographic information system, fire prevention, mapping.

\section{Introduction}

Each summer wildfires burn 500000 ha of forests in the European Mediterranean regions (source EFFIS). 90\% of forest fires are of human origin and most of them start in the wildland-urban interfaces. A better understanding of these spaces was obtained through numerous studies in the USA and Canada. The description and characterization of these interfaces have been developed at Irstea (Lampin C., 2009). To make operation easy and fast, an ArcGis extension was developed to create maps on a large area. A first prototype of the software was developed with funding from the FIREPARADOX Program (FP6) .The first operational version 
of this tool and user's guide (Lampin -Maillet et al, 2010) were created in 2010 with the support from the Ministry of Ecology and published and distributed to regional services.

The framework of the European FUME (Forest fires under climate, social and economic changes in Europe, the Mediterranean and other fire-affected areas of the world) program has defined the creation of a common tool to map rural urban interfaces (RUI). It is a WUI concept for all types of interconnections between the urban area and forest areas around, or wildlands with agricultural areas and with various types of vegetation. Within RUI, buildings and human infrastructures are closely mixed with fuel vegetation and create high wildfire risk. The dynamics can be controlled by land management and planning measures.

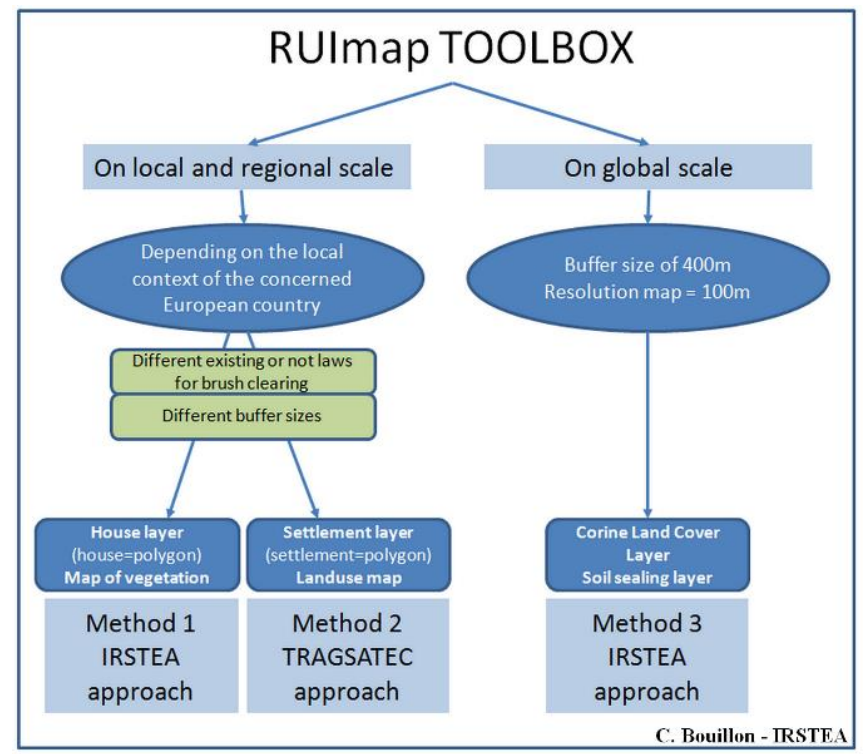

Figure 1. Schema of the tool

Three partners are involved in the creation and testing of this tool: Tragsatec, Spain; Irstea , France and the University of Sassari, Italy. Tragsatec developed a method for mapping interfaces on the local ( municipal) level. Irstea developed two methods, a local method by improving the method already set (Lampin\&Bouillon, 2011) and a global method, the European scale. The University of Sassari is responsible for testing and validating the results with data from three sites located in Spain, the Alicante region, in France, the Bouchesdu-Rhône and in Sardinia, Italy. All developments were made with the ESRI TM ArcGIS TM platform and were integrated by Tragsatec in a common software called RUImap (Figure 1). Some recent uses of the methods and maps presented in this paper show a direct operational use of the results to improve the knowledge of the territory under the RUI approach and mapping.

\section{Methods}

\subsection{Local scale Irstea}

In the methodology developed in France (C. Lampin -Maillet, 2009), RUI is defined according to the July 9th, 2002 French Forest Orientation Law which makes brush clearing obligatory within a maximum radius of 100 metres around each house located at a distance inferior to 200 metres from forests (Figure 2). 


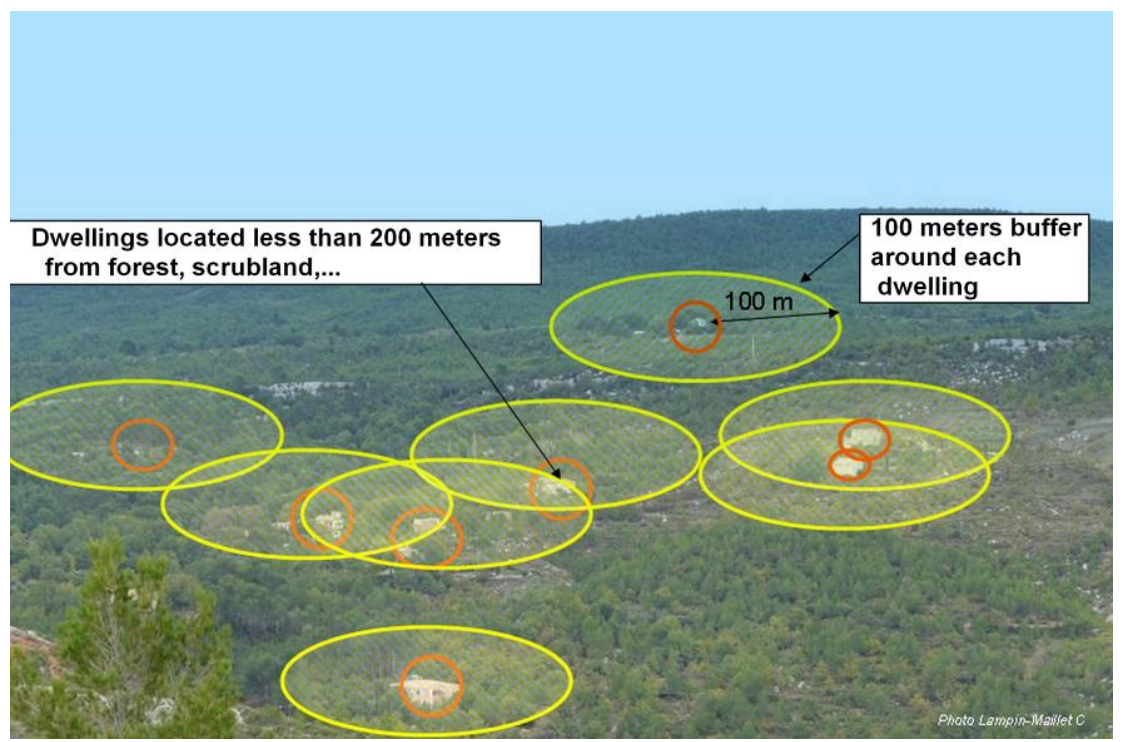

Figure 2. RUI definition

The 12 types of RUI (Figure 3) are created by integrating the density of buildings with a vegetation structure, more or less continuous. The process includes a combination of four housing configurations based on building density (isolated: from 1 to 3 buildings, scattered: from 3 to 50 buildings, dense: more than 50 buildings and very dense: more than 50 buildings at a distance of less than $15 \mathrm{~m}$ between buildings) and three vegetation connectivity types (null, low, high) based on a landscape metrics : Aggregation Index (AI) (Turner, 1990), which can be mapped using FRAGSTATS3.3@ software (McGarigal \& Marks, 1994).

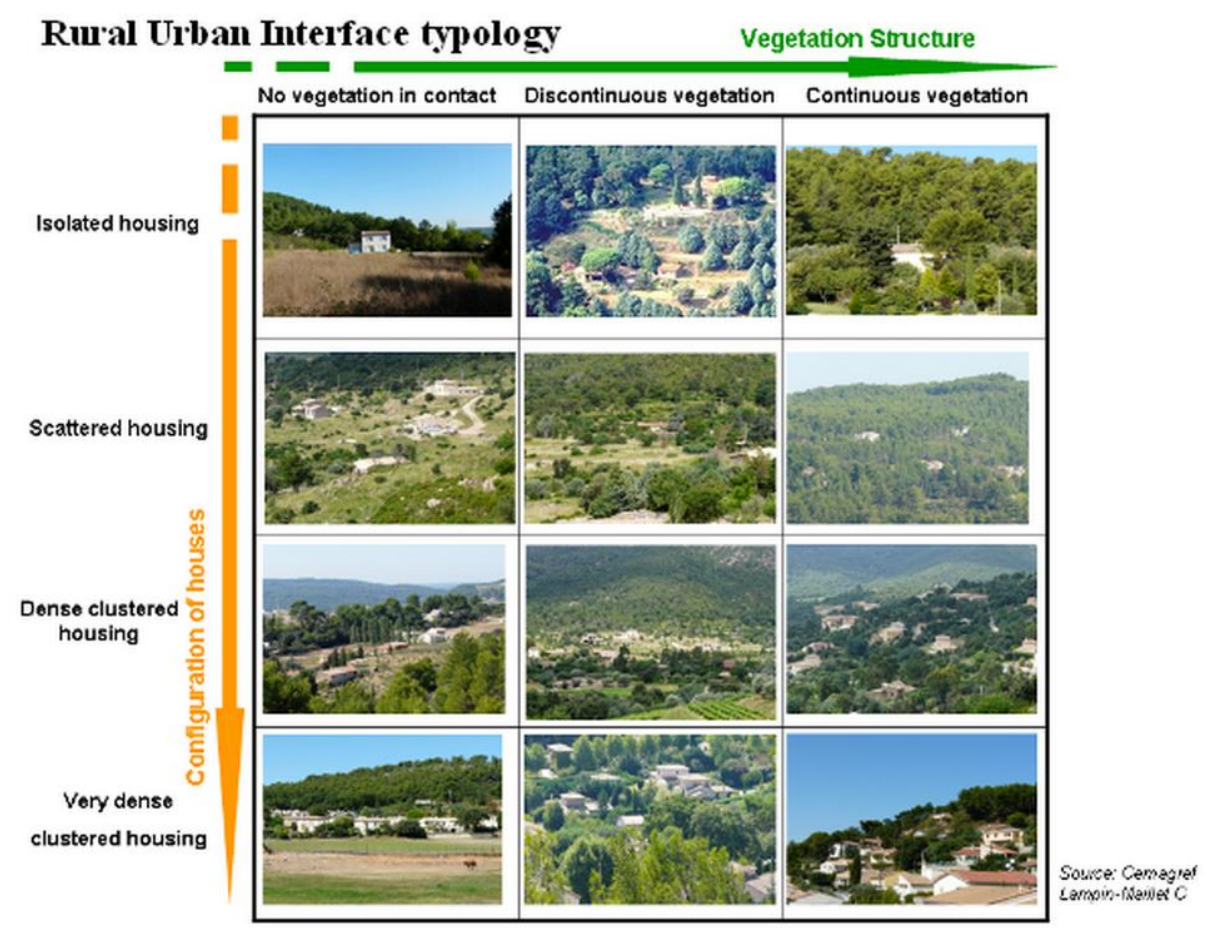

Figure 3. The 12 types of RUI

The map was created by the tool and set up with a colour code for an easy interpretation. (Figure 4) 


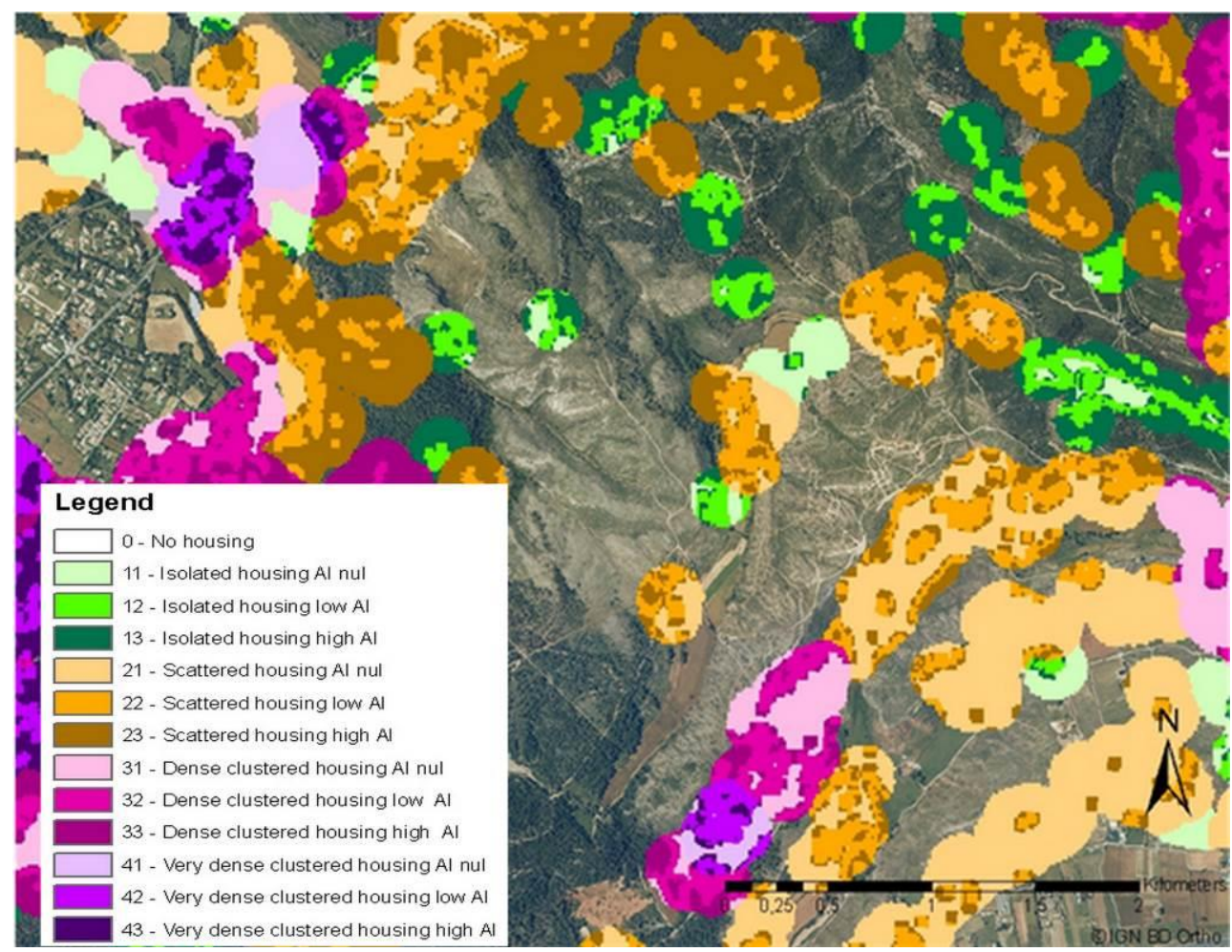

Figure 4 Local scale RUI map

\subsection{Methods Local scale Tragsatec}

The second local scale method was developed by TRAGSATEC. The method is based on three phases. First a settlement map creation with two layers : a land use cover (in Spain : SIGPAC) and a vegetation cover (the National Forest Map of Spain). The result of the union of the layers is a territory which is distributed in plots depending on the housing (Figure 5) - urban cores, spread buildings, isolated houses, etc... - and the different uses of land - forestry or agricultural -, taking as a basic aspect how the dispersion of the buildings is on the land and the landscape that surrounds them with the rules defined below:

- Urban area (plot > 50 ha)

- Habitat in agricultural areas ( 1 ha $<$ plot $<50$ ha, forest $<30 \%$ )

- Habitat in forest areas ( 1 ha $<$ plot $<50$ ha, forest $>=30 \%$ )

- Habitat dispersed in agricultural area (plot $<1$ ha , forest $<30 \%, 3>$ buildings $>5$ )

- Habitat dispersed in forest areas (plot $<1$ ha , forest $>=30 \%, 3>$ buildings $>5$ )

- Habitat isolated agricultural area (plot $<1$ ha, forest $<30 \%$, buildings $<3$ )

- Habitat isolated forest area (plot $<1$ ha, forest $>=30 \%$, buildings $<3$ ).

The second phase is a buffer creation. The Rural-urban interfaces only are considered in settlements which are located at a distance inferior to $400 \mathrm{~m}$ from the forest (according to the Regional Spanish laws). A buffer is created around the established settlements from the first phase and its size depends on the difficulty in protecting the houses against fire. In the final phase the different types of RUI are defined from the type of settlement and vegetation-settlement connection around houses, the buffer for each type of settlement is the area called the rural-urban interface. 

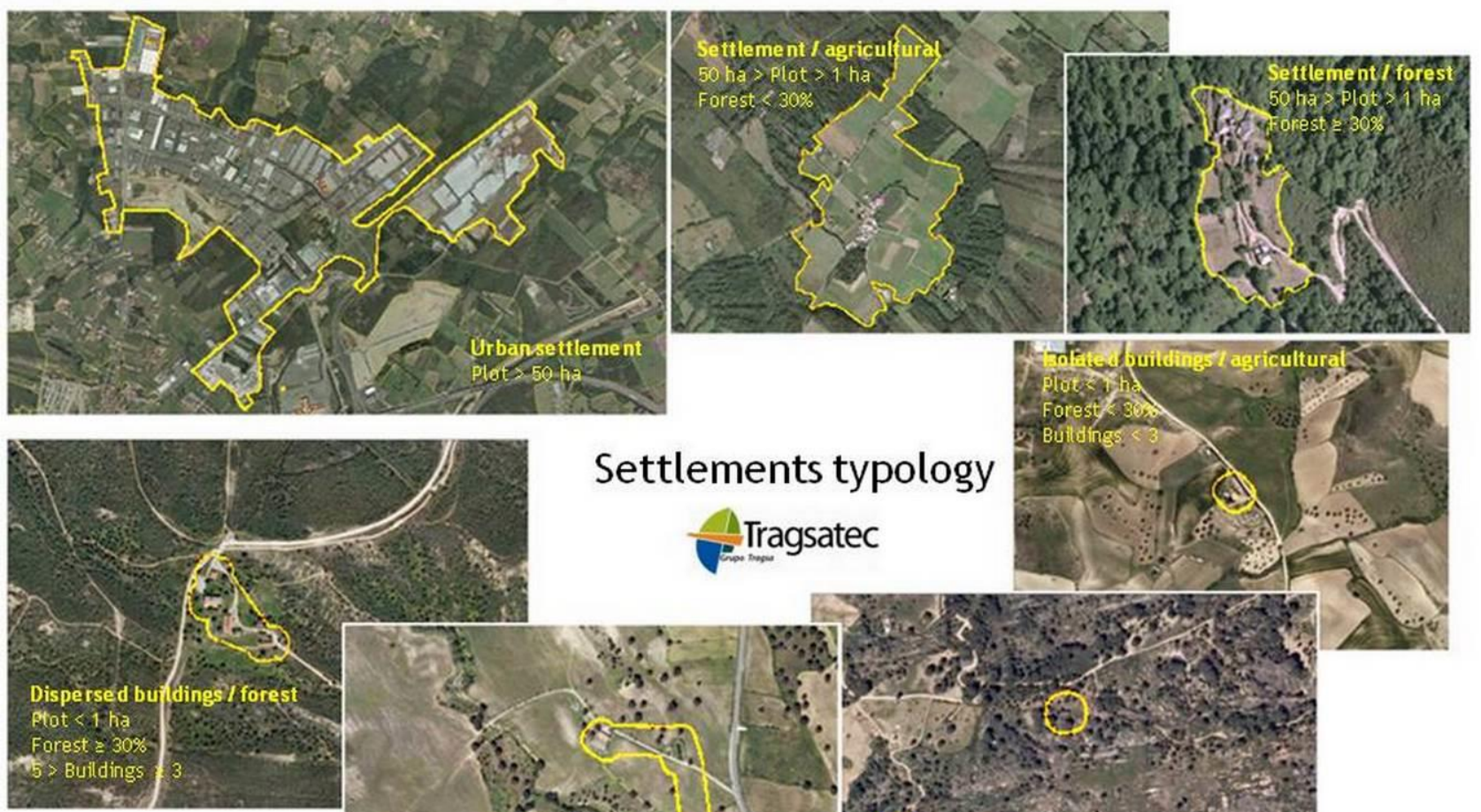

\section{Settlements typology} Aragsatec
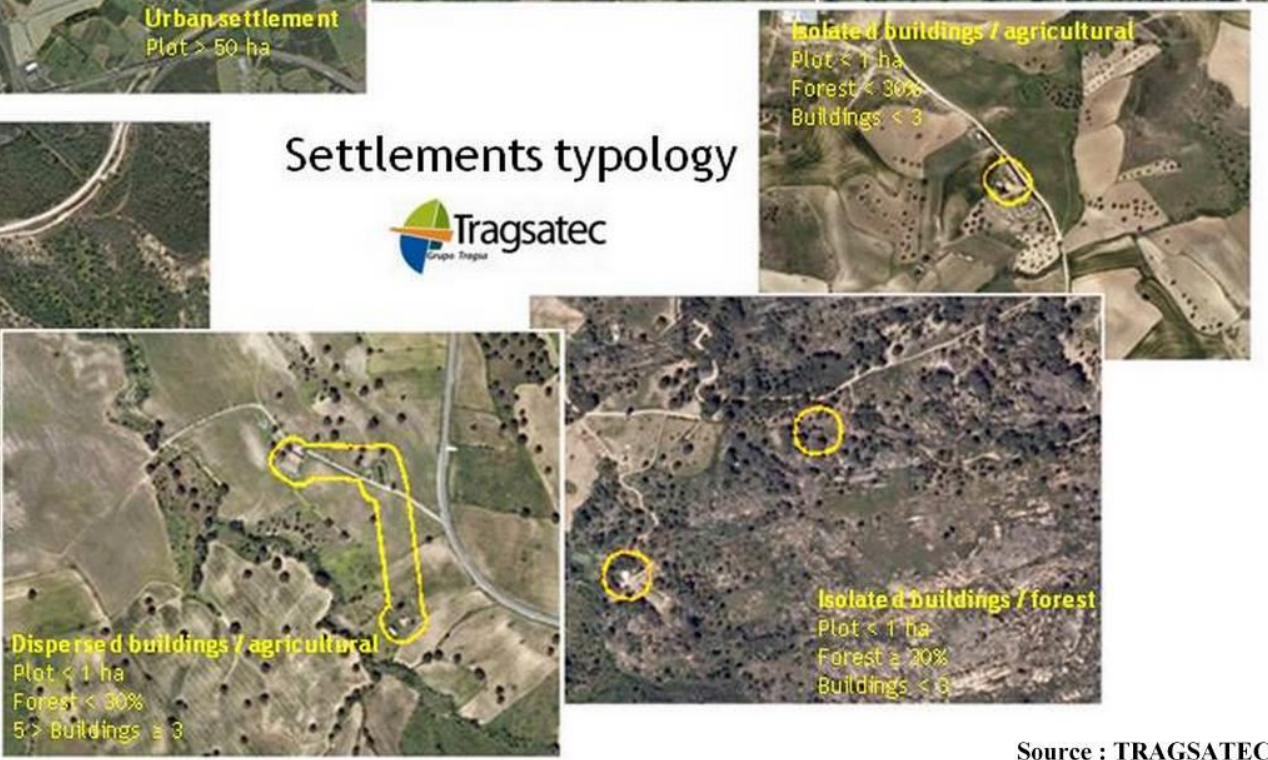

Source : TRAGSATEC

Figure 5. Tragsatec settlement typology-

The Rural-urban interfaces are considered in settlements which are located at a distance inferior to 400 $\mathrm{m}$ from the forest. This distance can be modified in the tool according to the laws of each country. Then the RUI map is created (Figure 6) by applying differentiated buffers, varying from 100m up to $400 \mathrm{~m}$, according to the type of habitat and risk.(Table 1)

Table 1-Buffer sizes

\begin{tabular}{|c|c|}
\hline Settlement Type & Buffer size \\
\hline Urban settlement & 400 \\
\hline Settlement in forested area & 300 \\
\hline Settlement in agricultural area & 200 \\
\hline Dispersed buildings in forested area & 300 \\
\hline Dispersed buildings in agricultural area & 100 \\
\hline Isolated buildings in forested area & 200 \\
\hline Isolated buildings in agricultural area & 100 \\
\hline
\end{tabular}




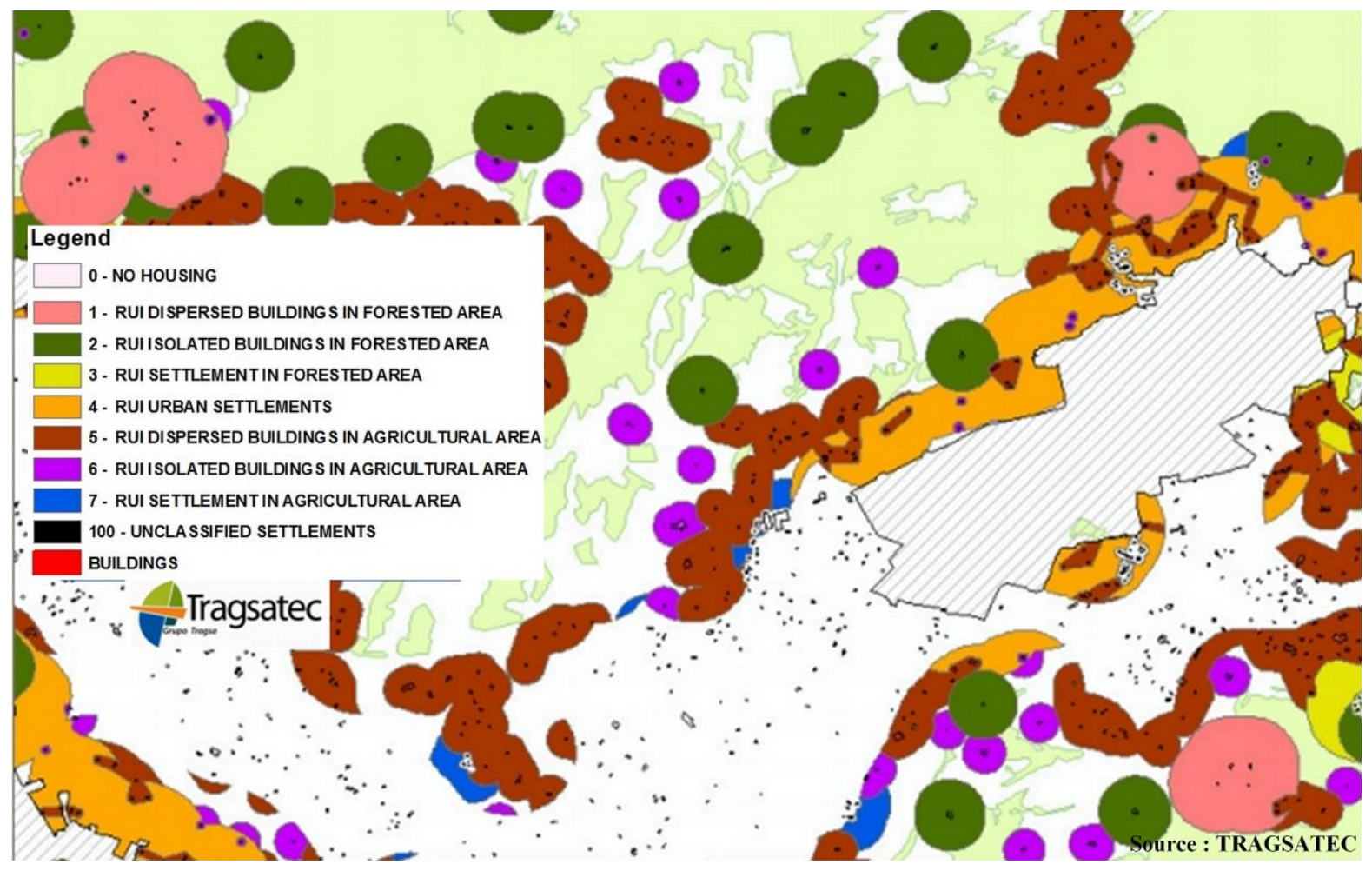

Figure 6. Map of RUI local scale - Tragsatec

\subsection{Global scale Irstea}

The global scale has been considered as the European level. This level of work has been taken into account in order to compare the situations and the importance of RUI in the different European countries.

The main database used is the 2006 CORINE Landcover with a pixel resolution of 100 metres. In order to characterize RUI, two main landcover types were used : vegetation and urbanization.

On the global scale, the rural urban interfaces are defined by a radius of 400 metres around houses located at less than 200 metres from forests or shrubland. The distance of 400 metres takes into account the perimeter where fuel reduction operations can be imposed on homeowners by different laws or regulations but also the possible burning of houses by spot fires.

The global rural urban interface map results from the combination of 2 criteria:

- the general land cover characterization (mineral, agricultural, sparse vegetated or forested area) resulting from the simplification of the Corine Land Cover database;

- the housing configuration (isolated, scattered, dense cluster housing) resulting from the combination of urban fabric classes of the Corine Land Cover database and from the soil sealing database.

A nine class typology was created during the process with a repartition of housing in three classes : isolated, scattered and dense, combined with different contexts : mineral, agriculture or sparse vegetation and forest. (Figure 7) 


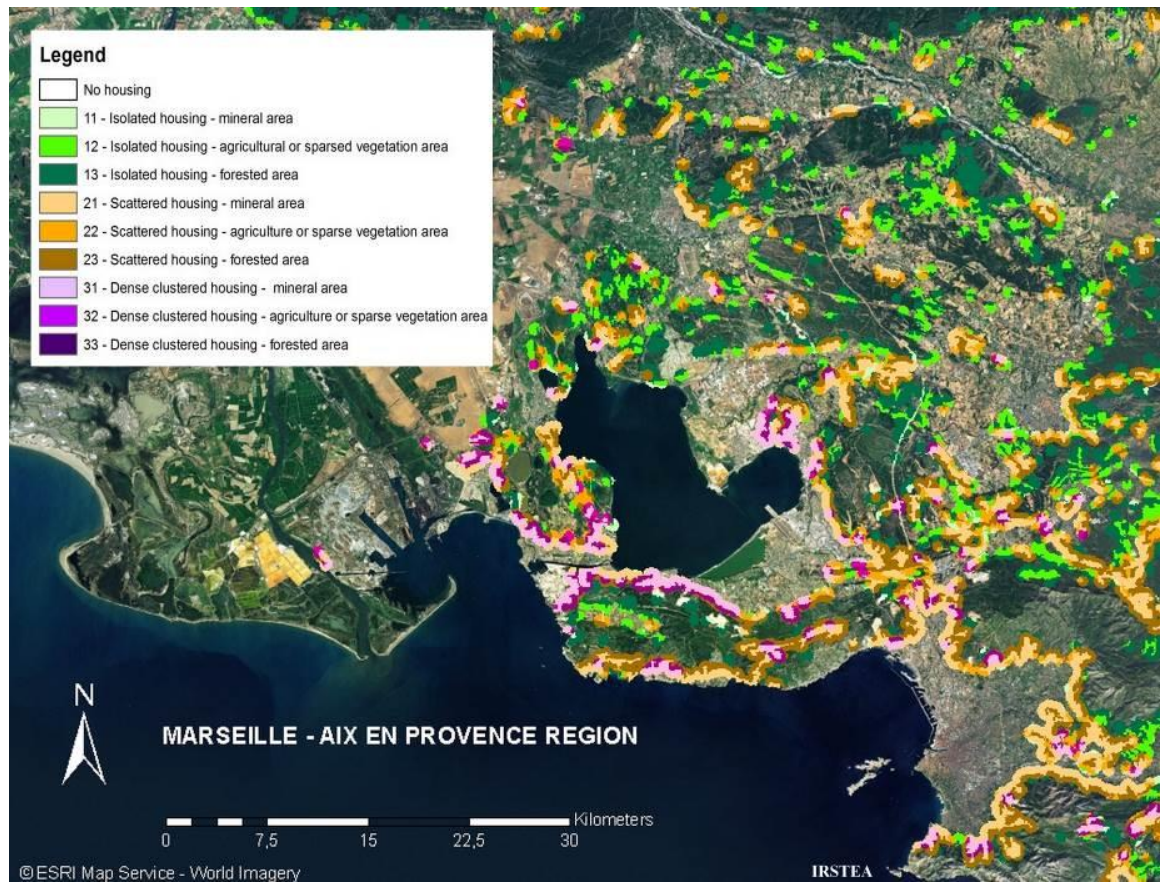

Figure 7. Global RUI map

\section{Results}

\subsection{The RUImap software}

This tool called RUImap (Figure 8) is an extension for ESRI ${ }^{\mathrm{TM}} \operatorname{ArcGis}^{\mathrm{TM}}$. It was designed to run the three methodologies detailed above automatically and to gain in time and easiness. Each partner developed some parts of the tool. The Irstea local and global scale modules were developed with the Python programming language using ArgGis ${ }^{\mathrm{TM}}$ functions. The TRAGSATEC local scale was written in VBA language. The design and integration of the module in the final version was made by Tragsatec.

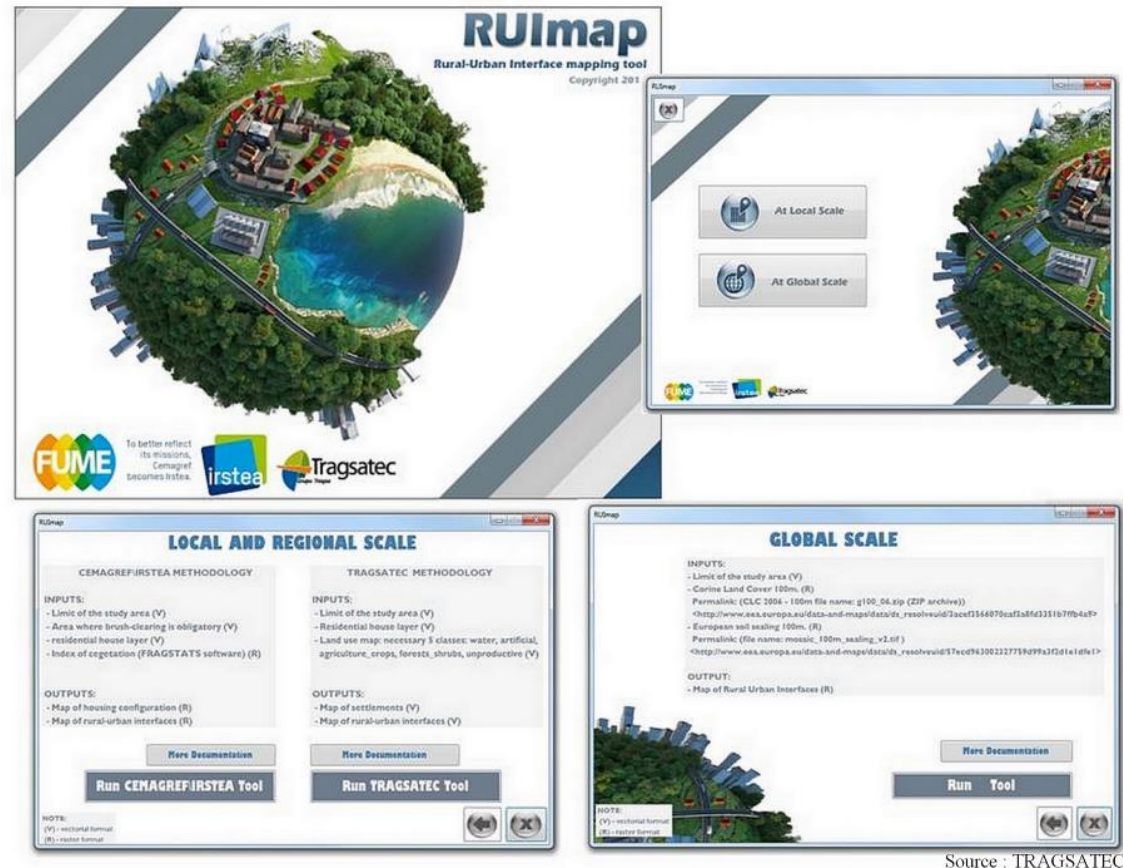

Figure 8. The RUImap software 


\subsection{Application of RUImap methodologies in different contexts}

The methodology was used in different programs and researches in Europe. Town managers (in charge of planning, risks and expenditure) could directly apply the methods developed and use the software designed for an easy-and-direct use. The tool could quickly create easily-readable maps, show the location and categories of Rural urban interfaces. The several outputs produced by the tool were compared and a significant coherence was noticed between the different methodologies. The knowledge of the territory and some comparisons of the outputs with the real situation show a good correlation between the software results and the real RUI distribution on the territory.

The two approaches, global and local, are both useful to know, describe and map the territory on different scales and with different definitions. The general map produced by the global tool can be used to have a general view of the territorial characteristics. Then, it is possible to use the local and regional scale to focus the areas and update the analysis.

The IRSTEA and TRAGSATEC methodologies can be considered as complementary. The first method developed by Irstea analyses the residential buildings and the presence and continuity of vegetation. The Tragsatec method works on the dwellings too but it takes into account the environment in which they are located (forested, urban, agricultural). When running the local tool with both methods, more information can be collected and a more complete description of single RUI contexts can be obtained.

The use of the tool could be very useful for fire risk analysis on RUI scale and for local quantification of fuel load and continuity. The information with the direct knowledge of the general context is very important for the local fire risk assessment.

\section{Municipality of Arcos de Valdevez, Portugal}

The Portuguese National Fire Plan (2006) promoted fire prevention, population sensitization using passive means such as improvement of surveillance, detection and alert. It focused the need to protect the WUI/RUI through the establishment of defensible space of at least a hundred metres around the buildings and settlements. In this way, "WUImapping" has been used in different research projects. The local scale methodology was used in the European project MOVE (Methods for the Improvement of Vulnerability Assessment in Europe) to define the vulnerability of the territories in order to find a more cost-effective risk management (funded by European Commission (7th Framework Programme). (Figure 9) 

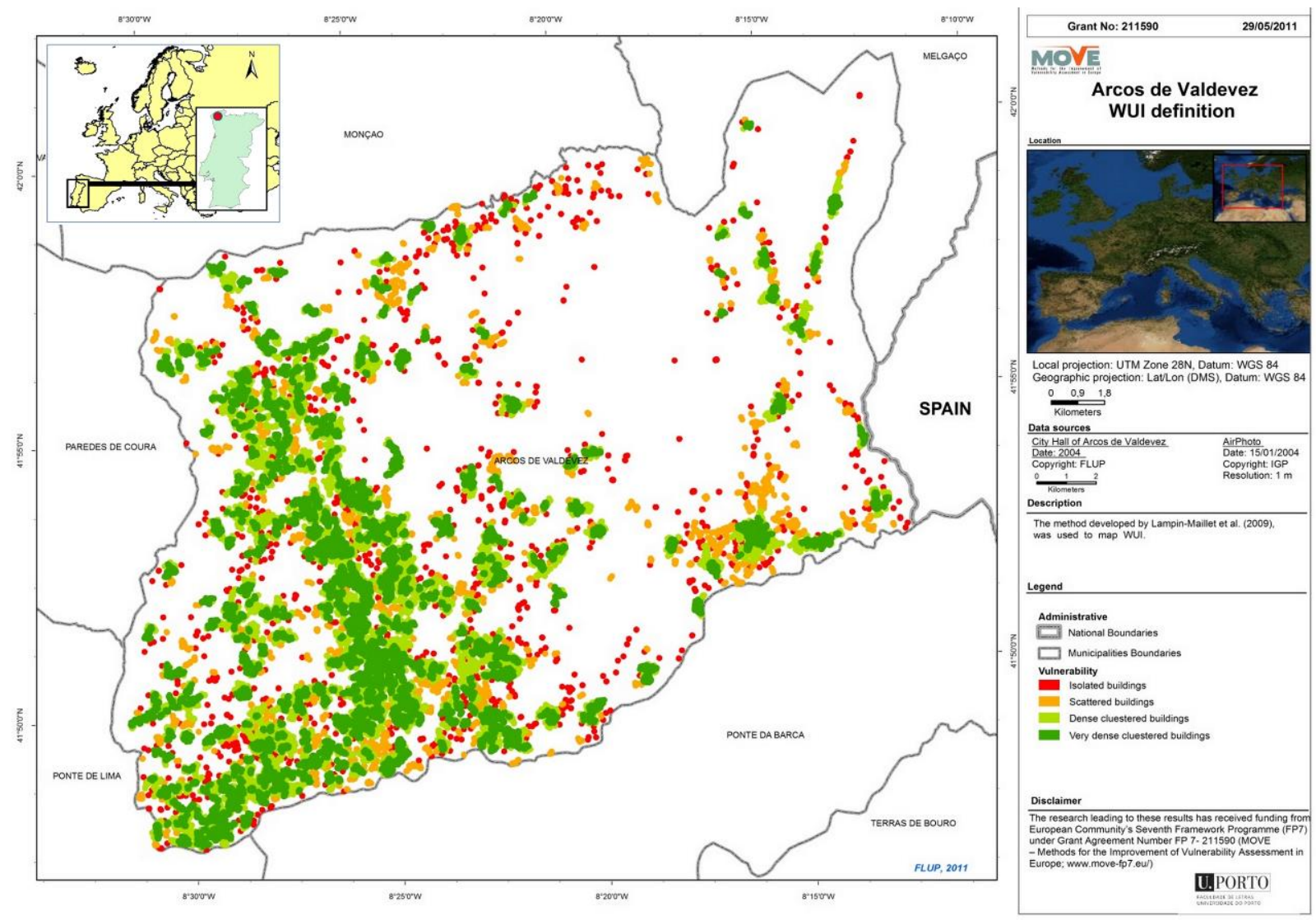

Figure 9. WUI mapping - Program MOVE

A project dealing with the implementation of a Forest Fire Risk Communication Program, will start in 2014 and will use the WUI/RUI methods in collaboration with several municipalities and stakeholders such as the Institute for Nature Conservation and Forests which is responsible for the coordination of all actions. The WUI/RUI typology will make possible a classification of the different forest fire prevention problems and will address them in a coherent way, both providing the capacity of transferability and capitalization.

\section{Golfo Aranci area, Sardinia, Italy}

Throughout most Mediterranean coastal areas, potential fire risk is really high for villages, tourist resorts, and people particularly in the summer. With a more important human presence and with extreme weather conditions, vegetation is highly flammable.

Therefore, developing planning policies is essential to find out strategies to prevent and reduce wildfire risk in WUI/RUI areas. Recently, several authors stressed the importance of estimating trends in expansion of WUI/RUI areas.

Tracking past and recent expansion trends allows to minimize their impact, to determine likely extent, location and pattern of WUI/RUI in the future, and to provide information for long-term land use planning and natural resource management. The study focuses on analysing and evaluating the temporal evolution of WUI/RUI areas in North Sardinia coastal regions in the 1954-2008 period with a great tourism development. (Figure 10)

Several simulations by Farsite ( fire spread and behaviour simulator) were also performed in order to evaluate the accuracy of this approach in providing useful information for mitigating fire danger and risk in WUI/RUI areas. 

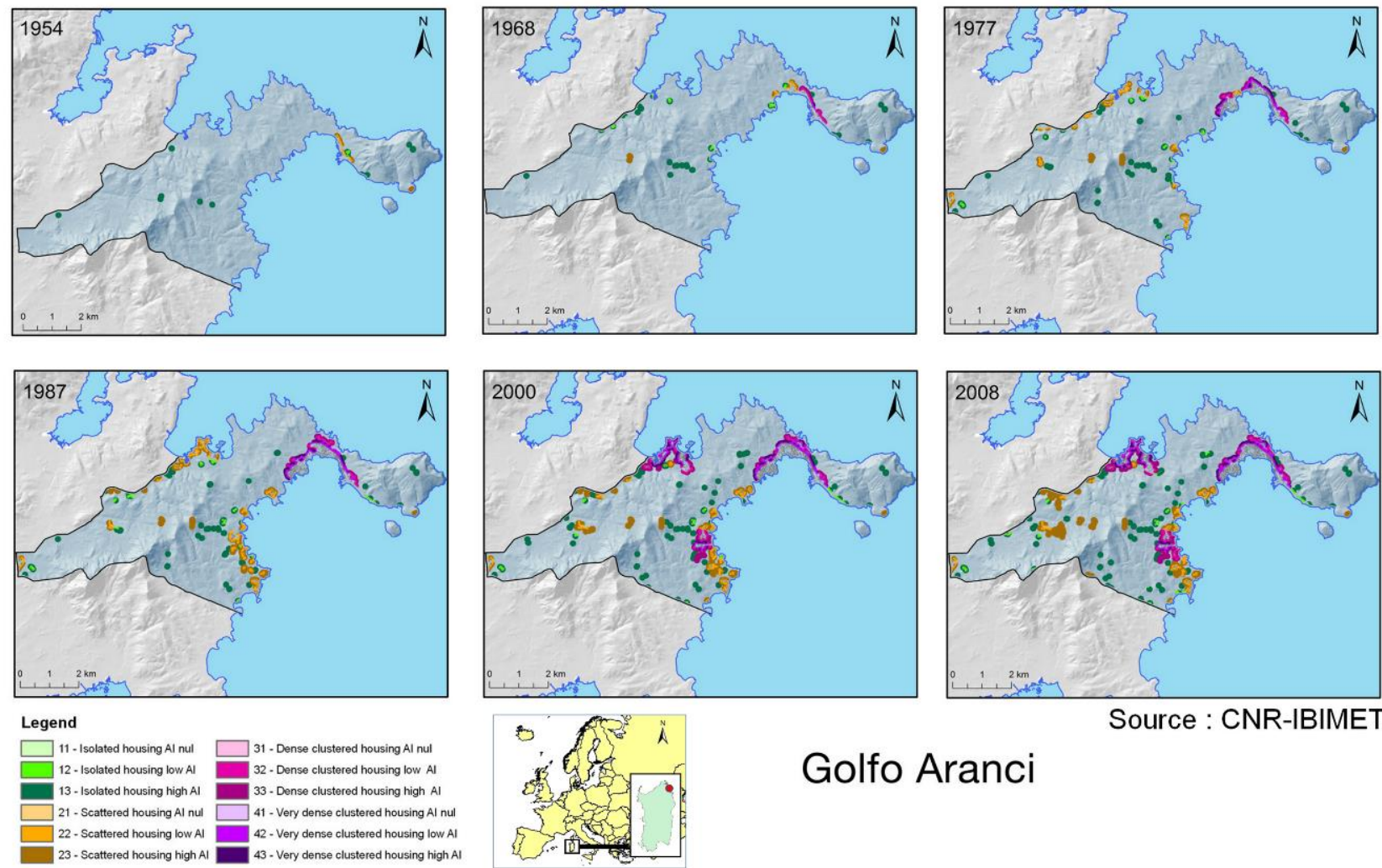

Source : CNR-IBIMET

Figure 10. Evolution of the WUI/RUI 1954 - 2008 - Gofo Aranci, Italy

\section{Oristano region, Sardinia, Italy}

In the province of Oristano (central-western Sardinia), the mapping and characterization of the interface areas and the adaptation of the methodology to the Iocal context were tested in 22 municipalities, 21 are in the forestry district of Arci-Grighine, using the RUImap tool and the local scale as a methodological basis.(Lampin-Maillet et al.2010a and 2010b) .

An adaptation of the RUI mapping procedure was performed, as the French procedure is closely linked to their definition of the RUI and to the brush clearing law (Law Art L.322.3). This adaptation permits the application of the methodology to the Italian territory where a precise definition of the interface is still lacking and were immediate identification of areas that may be more sensitive to the problem of forest fire does not correspond to Italy. The alternative use of this input data allowed us to divide the territory into a forest area and rural area rather than in an area with a requirement / non-requirement trimming.

In the derivation of the vegetation map, the use of aerial orthophotography and of the filter (ICS Index Soil color) has revealed the fragmentation of forest vegetation with satisfying results, highlighting areas of bare soil present in some portions of the territory. BCZ (Brush clearing zone) was not used in this procedure as it is different in Italy. The change in the size of the floating window has made it mandatory to change the thresholds that define classes. AI low e high have been fixed respectively to $0-88 \%$ and $>88 \%$.

The piedmont forest district of Arci-Grighine is an area with a high priority level in terms of land management and fire prevention actions. 
Among the different RUI types Isolated and Scattered housing and AI low and high are those that require the highest security costs as they have a large surface area exposed to the fire and are difficult to reach. The map of RUI ( figure 11) shows high-risk areas with very low population density and in the mountain ranges of Grighine (red) and the Monte Arci (blue). The last area was burned on July 4th, 2014 from a forest to a more dense housing RUI, causing huge damage to farms and dwellings.

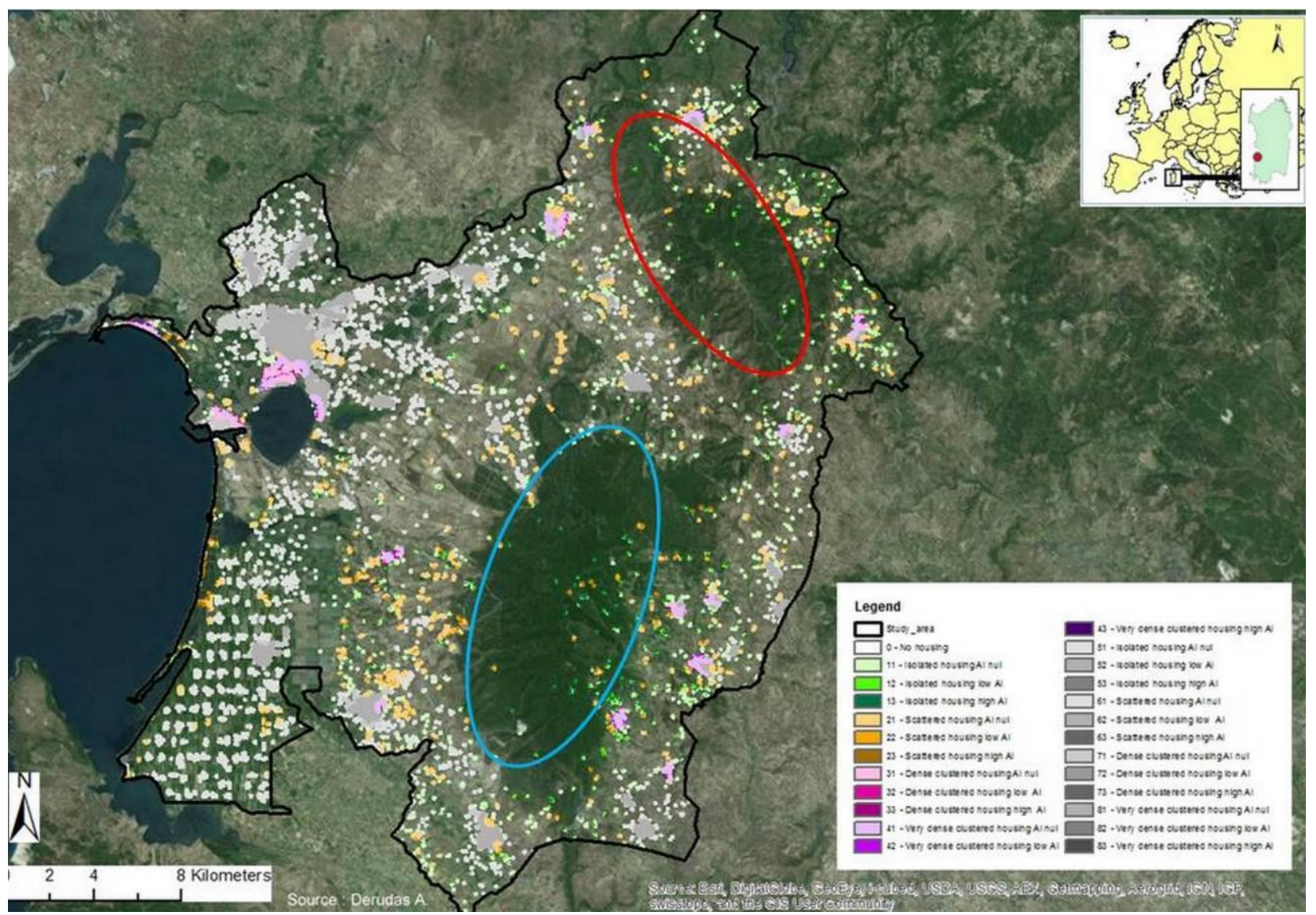

Figure 11- Priority zones to monitor, isolated houses, high vegetation aggregation

\section{Molentargius regional park, Cagliari, Italy}

The Molentargius regional park is an area of 1600 ha in the vicinity of Cagliari. The park stretches on wetland, lagoon areas (Ramsar convention) and abandoned salt flats frequented by numerous bird species.

The park area is also made of different terrestrial ecosystems with a patchwork of various vegetation: reed beds, meadows, groves and degraded scrublands interconnected with an a man-made system of some dwellings next to urbanization.

A plan was made to mitigate and lower the fire risk to human high value belongings like commercial buildings on the edge of the park.

The use of the RUImap software allowed to add information to the general knowledge of the park area, as a large part is included in an Rural Urban interface area. An analysis of the territory of the Molentargius regional park was performed (Figure 12) with the results obtained with the application of the RUImap software and the burned areas from 2005 to 2012. We can observe that most of the fires occurred in the areas where dwellings are surrounded by more or less dense vegetation. 


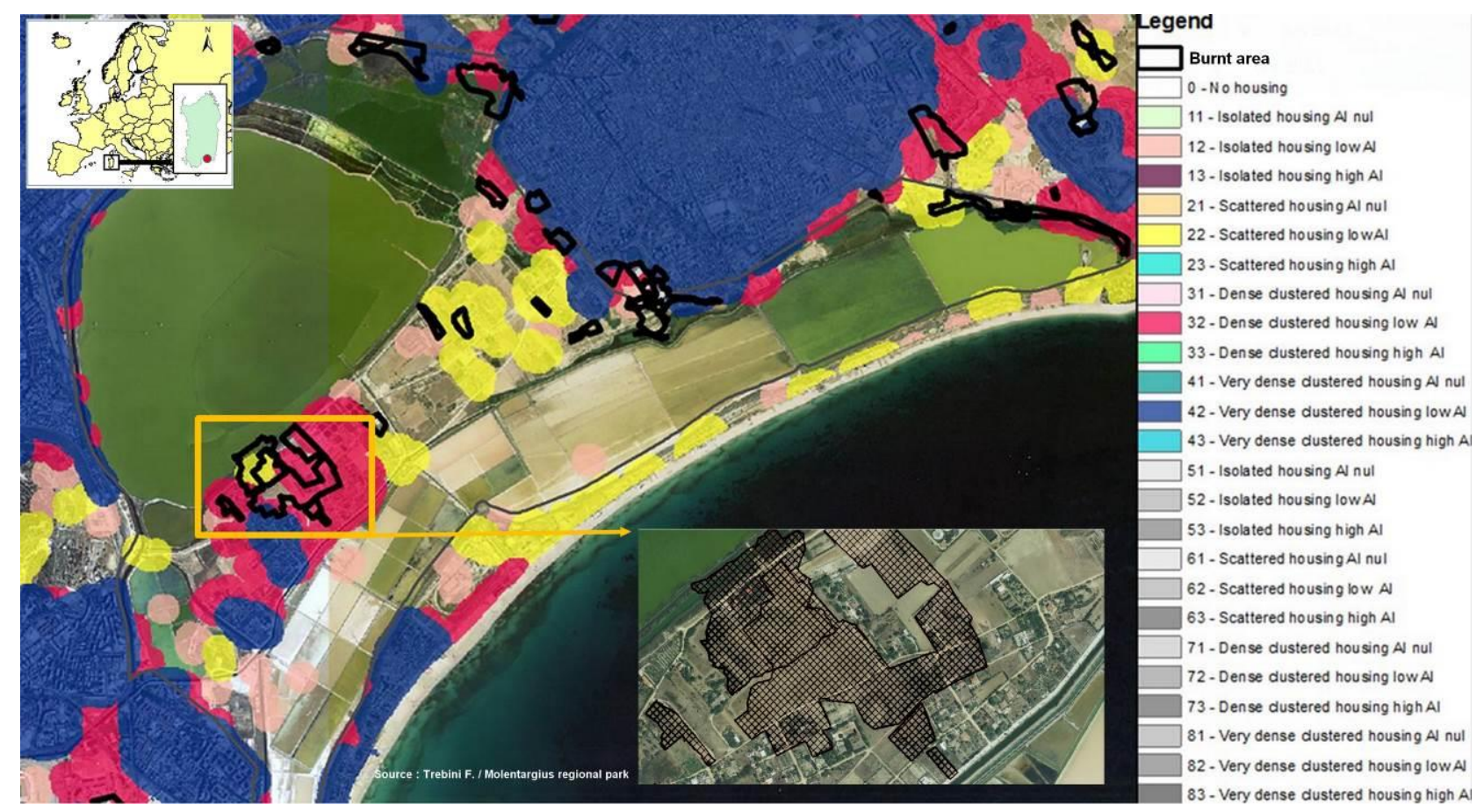

Figure 12. RUI map and burnt area

\section{Mimose village, Sinnai community, Sardinia, Italy}

In this chapter the study uses the RUImap local methodology for mapping interface areas. This method is different from the method indicated in the guidelines issued by the Department of National Civil Protection Plan. France and Sardinia have different fire protection requirements . RUImap tool was used to point out the differences between the two countries.

The main interesting points of these RUI cartography are :

- a better knowledge of the interface areas and understanding of the dynamics;

- the identification of the most immediate at risk areas for fire operators.

- In the design phase of fire prevention :

- the identification and estimation of the areas to be cleaned;

- the assessment of the scope of the areas at risk and the consequent dividing up fire fighting teams and equipment;

- the design of the escape routes for the population as well as firebreaks or areas of cleaning required in the vicinity of the towns;

- the evaluation of suitable location basins or points for fire water supply.

The mapping urban-forest interfaces is one of the key elements for assessing the risk of fire. It is indeed a method to identify the critical present in an area and the sensitive points such as residences to be protected in case of fire, the presence of people and their assets. It is thus a valuable aid in the fight against fires through the knowledge of the spatial organization of housing in addition to being a tool to identify the people who live in urban-forest interfaces and so it is important to provide information focused on the risk of fire for preventive purposes. 


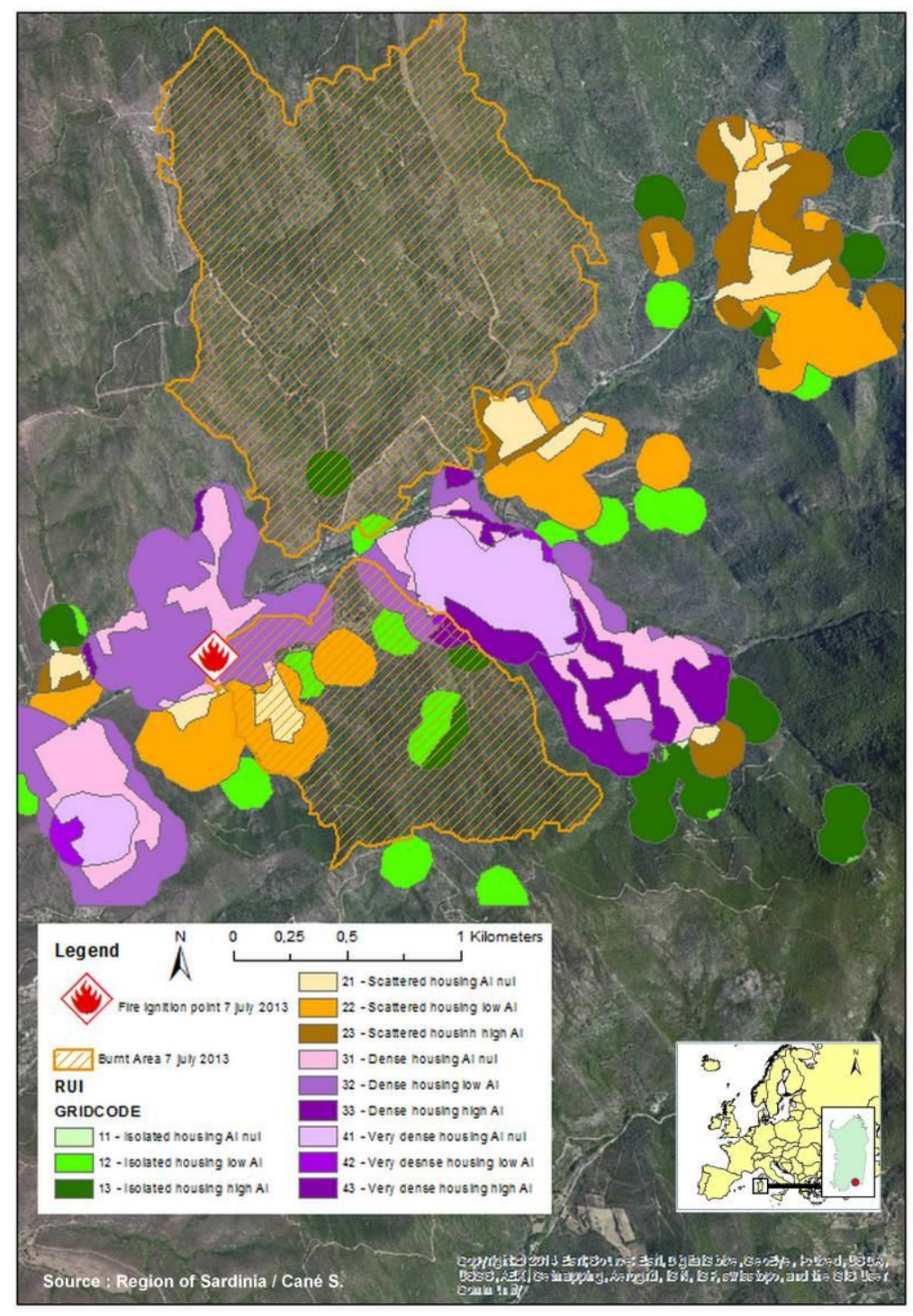

Figure 13. Mimose village -RUI map and burnt area

\section{Bouches-du-Rhône, France}

Irstea did a study for the regional ministry of the environment office. The aim was to get an overview of the RUI in the Bouches-du-Rhône department including the metropolitan area of Aix Marseille. The RUI of all the area was performed with two sets of data with a lapse of ten years. The results show an increase of $11 \%$ of the WUI area. The data were used later in the FUME program and related to fire historic data. The result shows a high number of ignition points located within the RUI zone with a higher density. The results are useful for stakeholders to make prevention action in this areas In the study area of the Bouches-du-Rhône the evolution of the RUI between 1999 and 2009 shows changes in the composition and areas of RUI. The first results concerning housing configuration show a global intensification of urbanization in the area with several trends. The densification of the already built RUI zones evolve towards higher density classes. The densification concerns also isolated housing with an increase despite planning policy recommendation over soil sealing of the territory. The main cause of this fact is an increase of the urban territory on the outskirts of the metropolitan area of Aix-Marseille. The attractiveness of southern France for its climate and lifestyle is part of the increase of built areas even in the remote towns with cheaper building prices. 
According to figures it is possible to give some conclusion. The area of the RUI is increasing globally by $10 \%$. The main increase in RUI types occurs principally in dense areas.
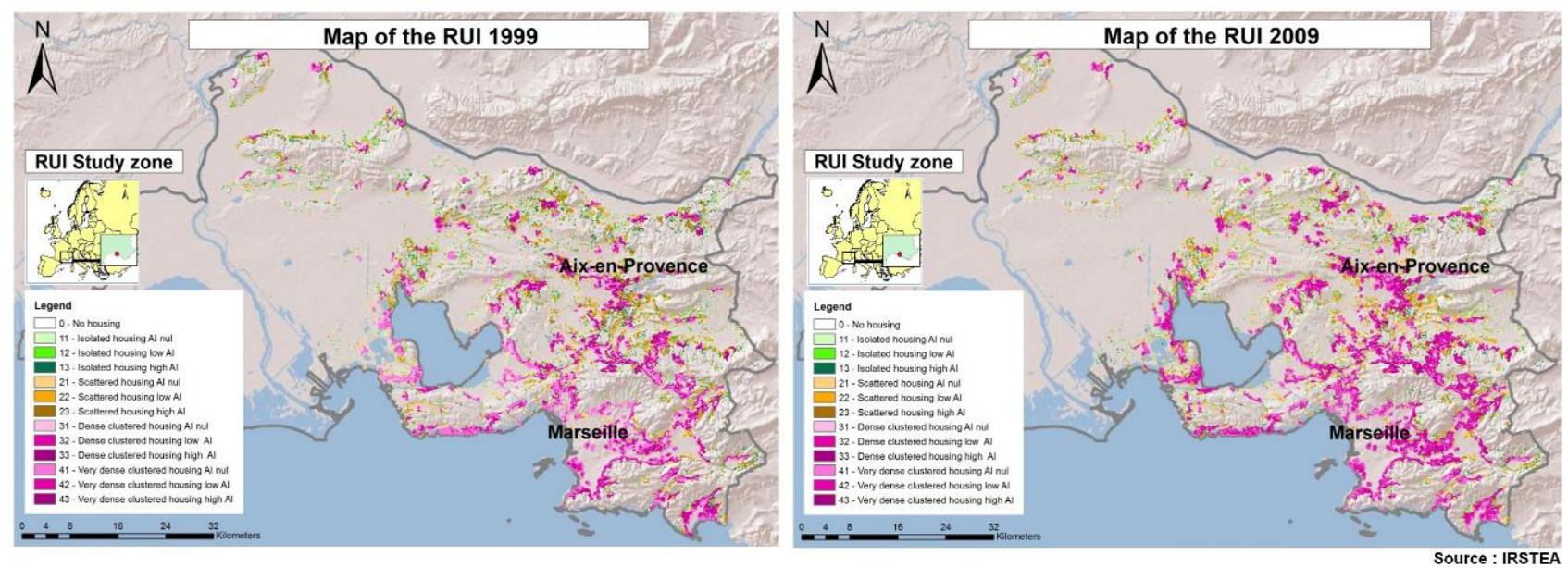

Figure 14. Bouches-du-Rhône, France :RUI evolution 1999-2009

\section{Conclusion}

The several outputs produced by the tool were compared and a genuine consistency between the obtained maps was noticed. The direct knowledge and some surveys in the territory are useful to compare the outputs with the real situation. A clear agreement between the software results and the RUI distribution on the territory was checked.

The two approaches, global and local, are both useful to know, describe and map the territory on different scales and definition. The general map that the global tool produces can be used to have a general view of the territorial characteristics on the regional scale and to focus the areas where the use of the local tool would complete the analysis.

In a general interpretation of the local tool application, the IRSTEA and TRAGSATEC methodologies could be considered as complementary. The first method developed by Irstea analyses the residential buildings and the presence/continuity of vegetation; the Tragsatec one also works on the dwellings but it considers the environment (forested, urban, agricultural) in which they are located. Running the local tool with both methods, more information can be collected and a more complete description of single RUI contexts can be obtained.

The use of the tool could be very advantageous for fire risk analysis on RUI scale, and for local quantification of fuels charge and continuity. The information, associated with the direct knowledge of the general context is very important for the local fire risk assessment.

The growing of RUI zone in all the Mediterranean study sites is a challenge for community leaders. This zone is at high risk due to numerous fire ignition density in a zone of human density and high valuable goods. The RUI expansion is a problem for prevention, organisation and fire-fighting. It increases the costs of protection as in these areas great losses are observed when a fire occurs. (human lives, houses).

RUI mapping can participate to prevent devastating loss for homeowners through assessment of information, to protect homes and lives in a better way in the interface where "lives community at risk". 


\section{Acknowledgements}

The research leading to these results has received funding from the European Union Seventh Framework Programme (FP7/2007-2013) FUME program (Forest Fires under Climate, Social and Economic changes in Europe, the Mediterranean and other fire-affected areas of the world) under grant agreement $n^{\circ} 243888$ and Sixth Framework Programme. (FP6/2002-2006) FIRE PARADOX program under contract no. FP6-018505.

Produced with the support of the Ministère de l'Ecologie, de l'Energie, du Développement Durable et de l'Aménagement du Territoire - France.

\section{Technical details}

RUImap is an extension for ESRI ${ }^{\mathrm{TM}} \operatorname{ArcGis}^{\mathrm{TM}}$ v9.3.1, Spatial Analyst ${ }^{\mathrm{TM}}$ and $\operatorname{ArcInfo}^{\mathrm{TM}}$ licences required. Available for free on request: contact christophe.bouillon@irstea.fr

\section{References}

Casula, F (2013) Wildland Urban Interface: Mapping and Wildfire Risk Assessment, PhD thesis, (University of Sassari, Sassari, Italy)

Farina A.(2001) Ecologia del paesaggio, principi, metodi e applicazioni, UTET, Torino, Italy

Lampin-Maillet C (2009). Caractérisation de la relation entre organisation spatiale d'un territoire et risque d'incendie : Le cas des interfaces habitat-forêt du sud de la France. Thèse de doctorat, (université Aix-Marseille, Géographie- Structures et dynamiques spatiales, Aix-en-Provence, France)

Lampin-Maillet C, Jappiot M et al (2009) Characterization and mapping of dwelling types for forest fire prevention. Computers, Environment and urban systems 33,224-232.

Lampin-Maillet C, Bouillon C et al (2010).' Guide de cartographie et caractérisation des interfaces habitat-forêt'. Convention $\mathrm{n}^{\circ} 2008119$ 071. (Ministère de l'Écologie,de l'Énergie, du Développement durable et de la Mer. 68 p.)

Lampin-Maillet C, Jappiot M et al (2010). Mapping wildland-urban interfaces at large scales integrating housing density and vegetation aggregation for fire prevention in the South of France. Journal of Environmental Management 91(3), 732-741.

Lampin-Maillet C, Bouillon C (2011) WUImap : A software for mapping Wildland-urban interfaces in the mediterranean european context. Journal of Environmental Science and Engineering, 5, 631642.

Madrigal Olmo J, Ruiz J.A et al (2013) Characterization of wildland-urban interfaces for fire prevention in the province of Valencia (Spain). Forest Systems 201322 (2), Short communication, pp. 249-254.

McGarigal K. (2002), Landscape Pattern Metrics Chapter of Encyclopedia of Environmentrics, Vol. 2, John Wiley \& Sons, Sussex, England, , pp. 1135-1142.

McGarigal K, Marks, B. (1994) Spatial patterns analysis program for quantifying landscape structure. FRAGSTATS version 2.0. Forest Science Dept, Oregon State Univ., (Corvallis, OR, USA)

Plano Nacional de Defesa da Floresta Contra Incêndios (PNDFCI). Resolução do Conselho de Ministros n. ${ }^{\circ}$ 65/2006, N 102 DIÁRIO DA REPÚBLICA — I SÉRIE-B, 3511 ,(Lisboa, Portugal)

Piano Regionale di previsione, prevenzione et lotta attiva contro gli incidi boschivi 2014-2016, Regione autonoma della sardegna. Deliberazione, N. 14/41 del 18.4.2014, (Cagliari, Italy)

Website FUME program (Forest Fires under Climate, Social and Economic changes in Europe, the Mediterranean and other fire-affected areas of the world). http://fumeproject.uclm.es/

Turner, M.G. (1990). Landscape changes in nine rural counties of Georgia. Photogrammetry Engineering and Remote sensing. 56, 379-386 